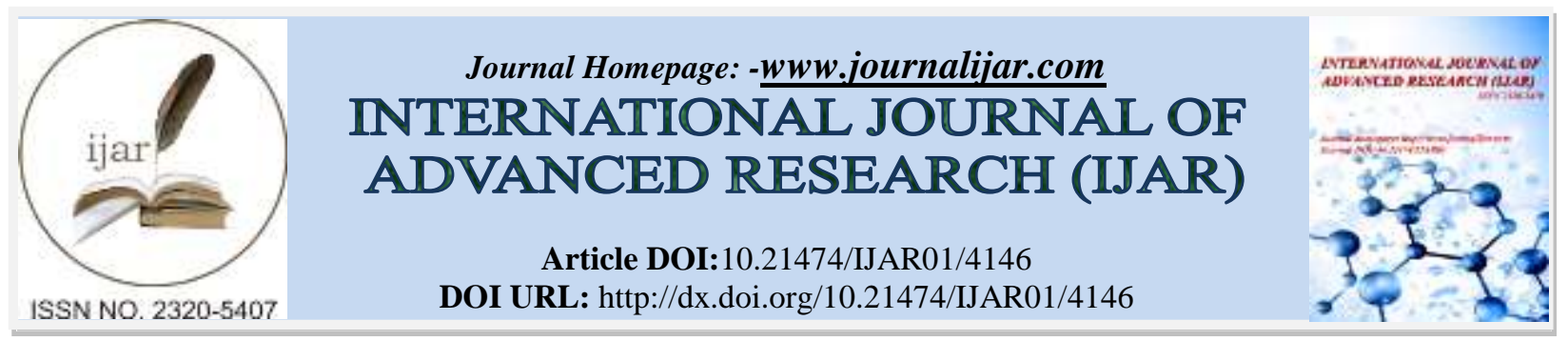

RESEARCH ARTICLE

\title{
SINGLE NUCLEOTIDE POLYMORPHISMS (SNPS) IN PAGE FAMILY MEMBER 4 (PAGE4) GENE IN MEN WITH BENIGN PROSTATE HYPERPLASIA FROM IRAQ.
}

Linda, F. Abdul-Sattar ${ }^{1}$, Hayder, I. Al-Ameery ${ }^{2}$ and Abdulwahid, B. Al- Shaibani ${ }^{3}$.

1. Medical Tools Department, Director of Materials Researches, Ministry of Science and Technology, Baghdad, Iraq.

2. Department of Urology, Al-Yarmook Teaching Hospital, Baghdad, Iraq

3. Medical and Molecular Biotechnology Department, College of Biotechnology, Al-Nahrain University, Baghdad, Iraq.

\section{Manuscript Info}

Manuscript History

Received: 12 March 2017

Final Accepted: 07 April 2017

Published: May 2017

Key words:-

SNPs, PAGE4 gene, Benign prostate hyperplasia

\section{Abstract}

This study was aimed to determine the single nucleotide polymorphisms (SNPs) in PAGE family member 4 (PAGE4) gene in men with benign prostate hyperplasia from Iraq. Blood samples were collected and molecular analysis of PAGE4 has been studied by using PCR. A primer was designed for amplification of first region which included (exon1, intron1, exon2 and part of intron2 ) of that gene. It was found that this region of gene appeared as a single band, 1491bp in size. Single nucleotide polymorphisms (SNPs) were determined in this region using DNA sequencing technique. Then, nucleotide sequences were aligned with control group (healthy men) and with NCBI.

Results also showed that seven polymorphisms were detected in first region of PAGE4 gene; six of them were substitution polymorphisms while one was addition polymorphism. Upon such findings, it can be concluded that some single nucleotide polymorphism in PAGE4 gene may affect gene expression.

Copy Right, IJAR, 2016,. All rights reservese

\section{Introduction:-}

Benign prostatic hyperplasia (BPH), is a hyperplastic process of the fibromuscular stromal and glandular epithelial elements within the prostatic transition zone (Auffenberg, 2009). As the most common benign tumor found in men, it comes in the fourth series of the most common disease, after coronary disease, hypertension and diabetes (Roehrborn, 2011). It is also the most common condition affecting those men older than 50 years of age. In general, a wide variety of genetic factors are associated with tissue hyperplasia. Androgen related genes and metabolism genes are closely associated with prostate growth and function. PAGE family member 4 (PAGE4) gene belongs to the $G A G E$ family. The $G A G E$ genes are expressed in a variety of tumors and in some fetal and reproductive tissues. Among all PAGE genes expressed in the testes of the adult human, PAGE4 is the only member of this family that is expressed in the prostate, It was located on chromosome Xp23.11, it has 5005bp spanning from nucleotide number 49673637 to 49678641 of chromosome X. It is up-regulated in the developing prostate and aberrantly expressed in benign prostate hyperplasia and prostate cancer (Zeng et al., 2013). The polymorphisms of PAGE4 gene associated with BPH found to predict tumor formation and prognosis (Bechis et al., 2014). So, PAGE4 gene was representing a surrogate marker for predicting BPH developing later in life (Mullins et al., 2008). 


\section{Material and Methods:-}

Blood samples were collected from 80 men with benign prostate hyperplasia, with mean age 68.7 years, 10 samples of them with serum prostate specific antigen between $4-10 \mathrm{ng} / \mathrm{ml}$ were selected from eighty samples in this study for detection of polymorphisms in first region of PAGE4 gene. Besides, 5 samples of blood from healthy men with median age 66.6 years as control. The DNA was extracted from blood samples using, the gSYNCTM DNA Extraction Kit, Geneaid, Korea. The extracted DNA from each sample used as a template for $20 \mu$ PCR reactions, and using ProFi Taq PCR PreMix from Bioneer/ Korea, $2 \mu \mathrm{l}$ of $10 \mu \mathrm{m}$ from forward primer $/ 5$ TGTGAGTTTTGGAGCGGGAC- $/ 3$ and $2 \mu \mathrm{l}$ of $10 \mu \mathrm{m}$ from reverse primer $/ 5$ - TTGGTGGTTCCTCTTGCTGA-/3 and $5 \mu$ of DNA template. The mixture volume was completed to $20 \mu$ by adding demonized distal water. PCR process was conducted through 30 cycles with the following steps: denaturation for $30 \mathrm{sec}$ at $95^{\circ} \mathrm{C}$, annealing for 30 sec at $60^{\circ} \mathrm{C}$, extention for $1 \mathrm{~min}$ at $72^{\circ} \mathrm{C}$ and final extention for $5 \mathrm{~min}$ at $72^{\circ} \mathrm{C}$. In order to analyze the nucleotides sequences for all samples, DNA sequencing was performed in Microgene, Korea.

\section{Results and Discussion:-}

\section{Polymorphisms in first region of $P A G E 4$ gene:-}

Detection of polymorphisms in first region of PAGE4 gene was done by sending PCR product of the region that amplified by using first primer of product size 1491bp (Figure1). The first primer cover the regions: exon1, intron1, exon2 and part of intron2. In this region, seven polymorphisms were recorded. The type of polymorphisms and positions are described in table (1).
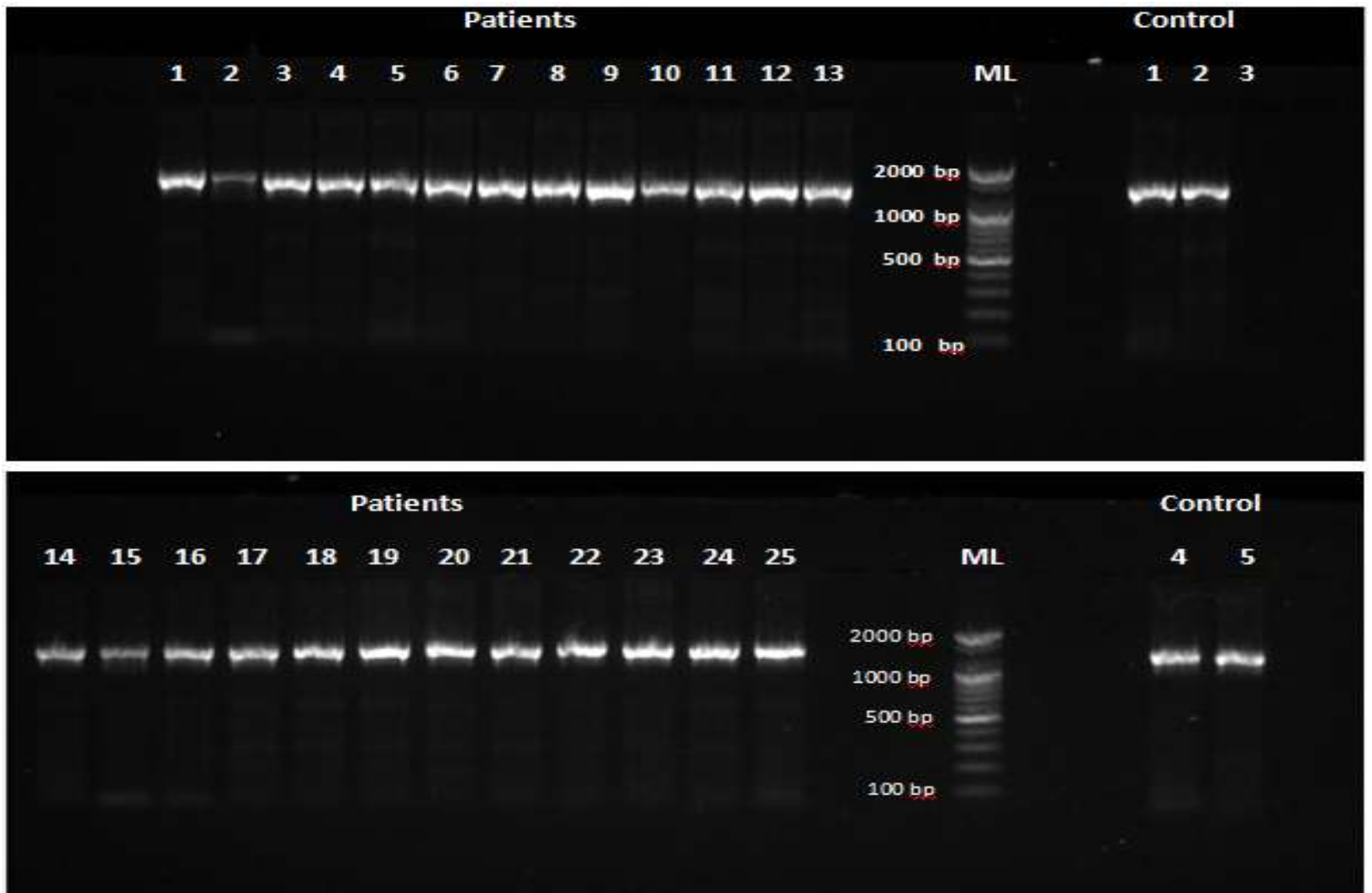

Figure 1:- Gel electrophoresis for PCR amplification with products size (1491bp) run on an agarose gel (2\%) for 1 hour at $5 \mathrm{v} / \mathrm{cm} 2$ in the presence of $100 \mathrm{bp}$ DNA Ladder marker. From 1-25 were PCR products for DNA extracted from blood samples of patients. From 1-5 Lane PCR products for DNA extracted from blood samples of healthy control. 
Table 1:- Polymorphisms in first region of PAGE4 gene in men with benign prostate hyperplasia.

\begin{tabular}{|c|l|c|c|c|c|c|}
\hline No. & Polymorphic & Type & Position & $\begin{array}{c}\text { Wild } \\
\text { type }\end{array}$ & $\begin{array}{c}\text { Polymorphic } \\
\text { type }\end{array}$ & $\begin{array}{l}\text { No. of } \\
\text { Patients }\end{array}$ \\
\hline 1 & $\mathrm{G} \rightarrow \mathrm{A}$ & Substitution & 49674439 & $\mathrm{G}$ & $\mathrm{A}$ & 4 \\
\hline 2 & $\mathrm{G} \rightarrow \mathrm{C}$ & Substitution & 49674450 & $\mathrm{G}$ & $\mathrm{C}$ & 6 \\
\hline 3 & $\mathrm{~A} \rightarrow \mathrm{T}$ & Substitution & 49674502 & $\mathrm{~A}$ & $\mathrm{~T}$ & 3 \\
\hline 4 & $\mathrm{~T} \rightarrow \mathrm{A}$ & Substitution & 49674508 & $\mathrm{~T}$ & $\mathrm{~A}$ & 2 \\
\hline 5 & $\mathrm{~T} \rightarrow \mathrm{C}$ & Substitution & 49674516 & $\mathrm{~T}$ & $\mathrm{C}$ & 6 \\
\hline 6 & $\mathrm{~A} \rightarrow \mathrm{T}$ & Substitution & 49674531 & $\mathrm{~A}$ & $\mathrm{~T}$ & 2 \\
\hline 7 & adding of C & Insertion & 49674780 & - & $\mathrm{C}$ & 1 \\
\hline
\end{tabular}

The sequences of first region in PAGE4 gene were aligned with control group (healthy Iraqi men) and with the reference sequence obtained from NCBI.

- First polymorphism: The sequence result revealed the presence of SNP G $\rightarrow$ A (table 3-10). The identified SNP was substitution polymorphism, nucleotide $G$ in control men replace with nucleotide A in BPH patients, also results revealed that this polymorphism was found in four from the ten patients (40\%)

- Second polymorphism: The sequence result revealed the presence of SNP $G \rightarrow C$ (table1). The identified SNP was substitution polymorphism, nucleotide $\mathrm{G}$ in control men replace with nucleotide $\mathrm{C}$ in BPH patients, also results revealed that this polymorphism was found in six from ten patients $(60 \%)$.

- Third and fourth polymorphism: The sequence result revealed the presence of two SNPs $(A \rightarrow T$ and $T \rightarrow A)$ as shown in table (1). The identified SNPs were substitution polymorphisms, in the first one, nucleotide A in control men replace with nucleotide $\mathrm{T}$ in BPH patients while, nucleotide $\mathrm{T}$ in control men replaced with nucleotide A in BPH patients, these two polymorphisms were found in 3 and 2 from the ten patients (30\% and $20 \%$ ) respectively.

- Fifth polymorphism: The sequence result revealed the presence of SNP $T \rightarrow C$ (table 1). The identified SNP was substitution polymorphism, nucleotide $\mathrm{T}$ in control men replace with nucleotide $\mathrm{C}$ in $\mathrm{BPH}$ patients figure. This polymorphism was found in six from the ten patients (60\%).

- Sixth polymorphism: The sequence result revealed the presence of SNP A $\rightarrow$ T (table 1). The identified SNP was substitution polymorphism, nucleotide $\mathrm{A}$ in control men replace with nucleotide $\mathrm{T}$ in BPH patients figure. This polymorphism was found in two from the ten patients (20\%).

- Seventh polymorphism: The sequence result revealed the presence of insertion polymorphism (table 1), C nucleotide was added in patient sequence, also results revealed that this polymorphism was found in one from ten patients $(10 \%)$.

Illustration of the alignment of nucleotides sequencing that covered by first primer of PAGE4 for men with BPH compared with control in NCBI center using automated sequencer and analyzed by BLAST data. The query number represents the current results while the subject represents the reference sequence (figure 2 and 3 in appendix) From the results above, seven polymorphisms were detected in first region of PAGE4 gene; six of them were substitution polymorphisms while only one was insertion polymorphism.

The most important single nucleotide polymorphism was insertion (addition of $\mathrm{C}$ nucleotide) in first region of gene that lead to change amino acid produced, this polymorphism caused a frame shift in the translational region. Frame shift changes had a higher effect on the polypeptide than missense or nonsense mutations. In substitution, only one amino acid changes, frame shift caused changes in all amino acids of a certain gene. In addition, this type of genetic diversity led to difference in copy number of gene (Sudmant et al., 2010). polymorphic variant of a gene may lead to the irregular expression or to the creation of an abnormal form of the gene; this may cause or be linked with disease and resistance to drug (Cardiol, 2014). So, these changes in reading frame and copy number could affect gene expression that associated with prostate hyperplasia risk. The present results agree with those obtained by (Helfand et al., 2013) who reported that the presence of one SNP (rs5945572) on chromosome Xp was associated with both BPH severity and BPH medication use. Genome wide association study (GWAS) identified 36 single nucleotide polymorphisms (SNPs) associated with prostate cancer and benign prostate hyperplasia (Lindstrom et al., 2011). A study by Rohramann et al., (2006) found that genetic factors contribute up to $72 \%$ of the risk of BPH. 


\section{Conclusion:-}

Single nucleotide polymorphisms were detected in first region of PAGE4 gene for patients suffering from benign prostate hyperplasia and these polymorphisms may affect gene expression, so, may be linked with pathogenesis of the disease.

\section{References:-}

1. Auffenberg, G., Helfan, B. and McVary, K. (2009). Established medical therapy for benign prostatic hyperplasia. Urol. Clin. North Am., 36: 443.

2. Bechis, K.., Alexander, M., Otsetov, G. and Rongbin, G. (2014). MD: Personalized Medicine for Management of Benign Prostatic Hyperplasia J. Urol.; 192 (1): 16-23.

3. Cardiol, R. ( 2014). Gene polymorphisms in Human. Human Gen., 22(1):1-12.

4. Helfand, B., Hu, Q. and Loeb, S. (2013). Genetic sequence variants are associated with severity of lower urinary tract symptoms and prostate cancer susceptibility. J. Urol., 189:845.

5. Lindstrom, S., Schumacher, F. and Siddiq, A. (2011). Characterizing associations and SNP-environment interactions for GWAS-identified prostate cancer risk markers--results from BPC3. PLoS One. 6:17142.

6. Mullins, C., Lucia, M. and Hayward, S. (2008). A comprehensive approach toward novel serum biomarkers for benign prostatic hyperplasia: the MPSA Consortium. J. Urol. 179:1243.

7. Roehrborn, C. (2012). Benign Prostatic Hyperplasia: Etiology, Pathophysiology, Epidemiology, and Natural History. In: Wein, A. J., Kavoussi, L. R., Partin, A. W., Peters, C. A., Novick, A. C., editors. Campbell-Walsh Urology. 10th ed. Philadelphia: Saunders; 2570-610.

8. Rohrmann, S., Fallin, M. and Page, W. (2006). Concordance rates and modifiable risk factors for lower urinary tract symptoms in twins. Epidemiology. 17:419.

9. Sudmant, H., Kitzman, O., Antonacci, F., Alkan, C. and Malig, M. (2010). Diversity of Human Copy Number Variation and Multi-copy Genes. Science.; 330(6004): 641-646.

10. Zeng, Y., Gao, D., Kim, J., Shiraishi, T. and Terada, N. (2013) . Prostate-associated gene 4 (PAGE4) protects cells against stress by elevating p21 and suppressing reactive oxygen species production. Am. J. Clin. Exp. Urol.;1:39-52. 


\section{Appendix:-}

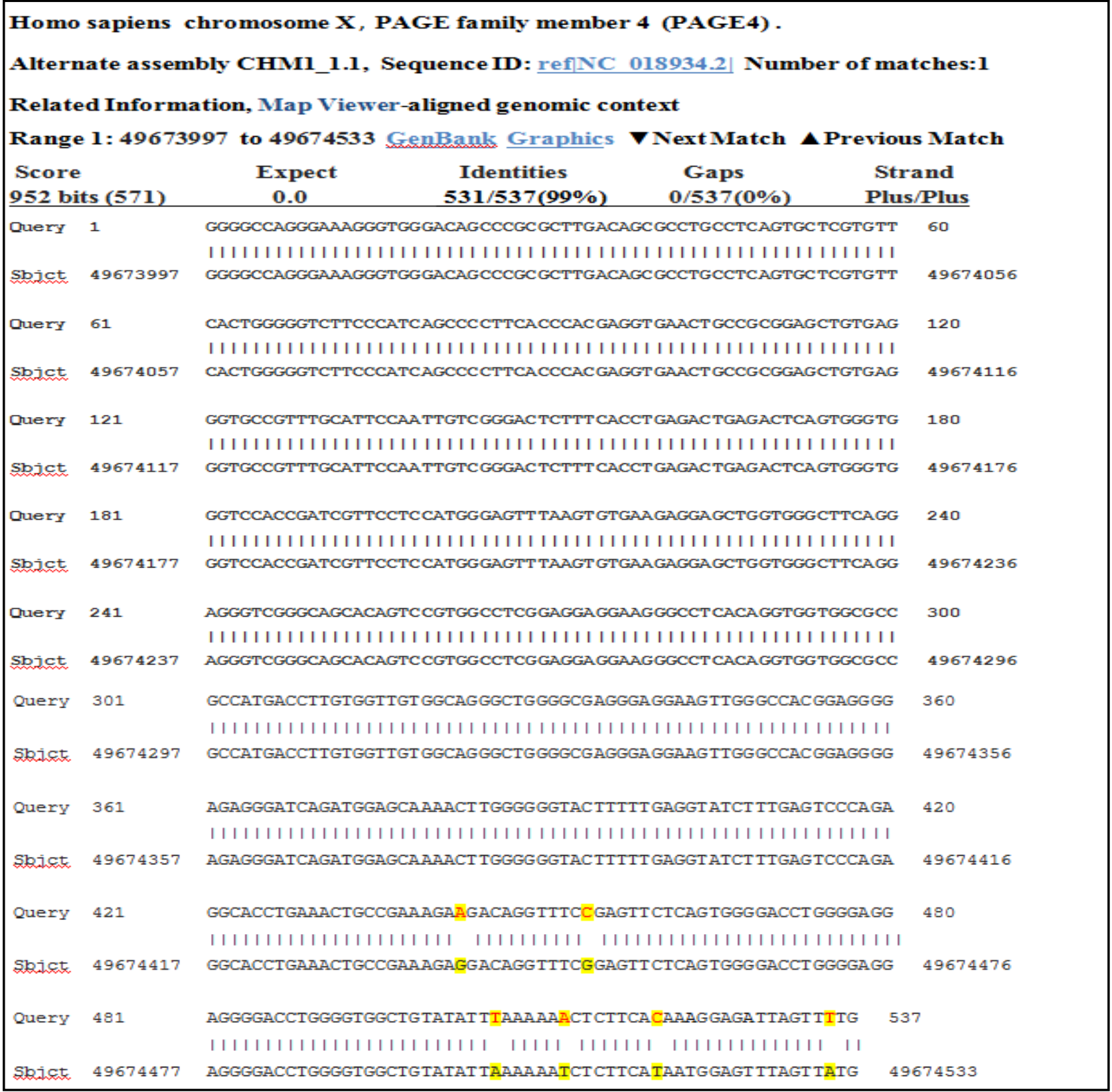

Figure 2:- Alignment of first region (forward strand) of PAGE family member 4 gene sequence of men with benign prostate hyperplasia using automated sequencer was analyzed by BLAST data, query number represents the current results while the subject represents the reference sequence. 


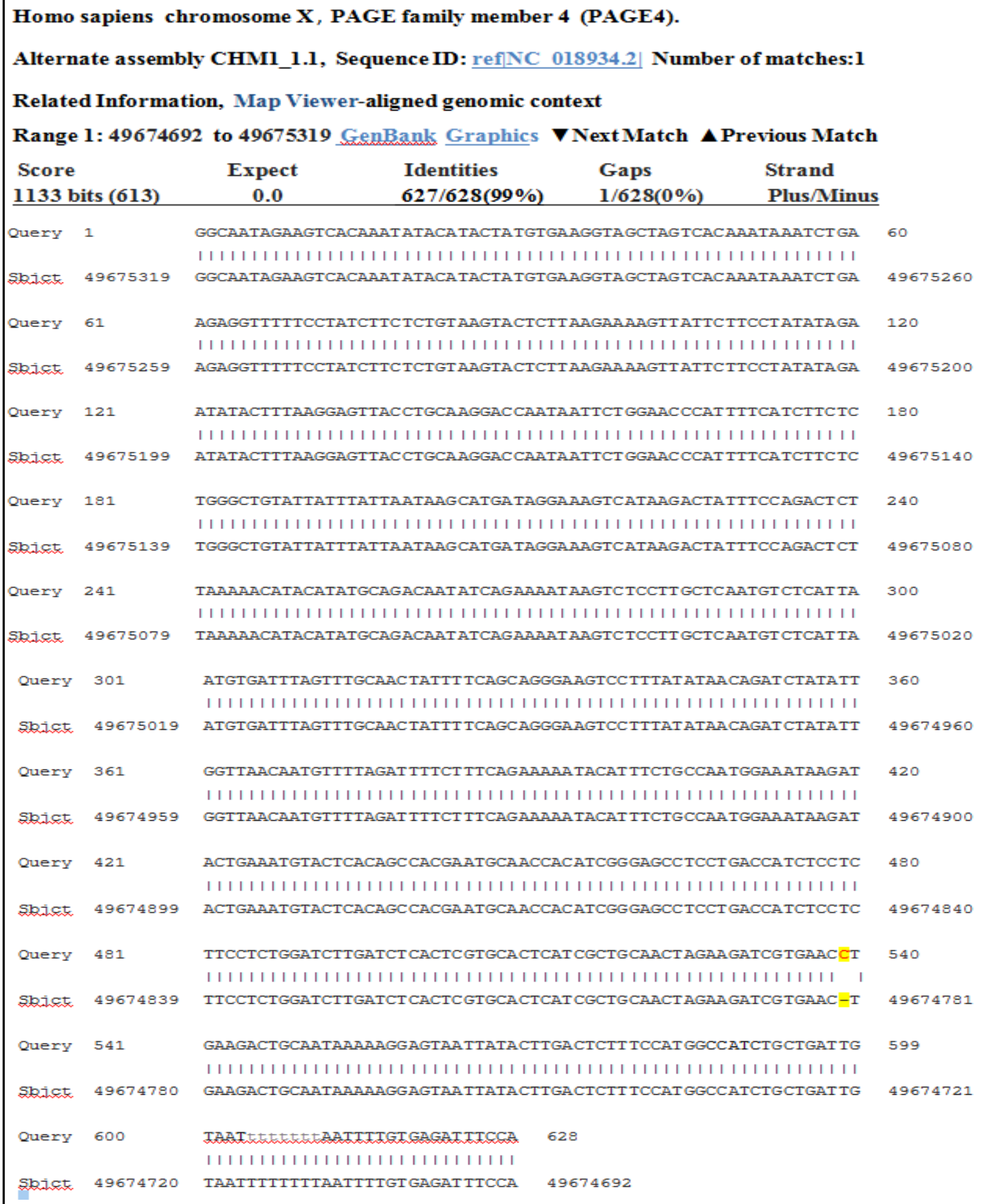

Figure 3:- Alignment of first region (reverse strand) of PAGE family member 4 gene sequence of men with benign prostate hyperplasia using automated sequencer was analyzed by BLAST data, query number represents the current results while the subject represents the reference sequence. 